\title{
PENGIRIMAN TEXT MELALUI GELOMBANG FM BERBASIS ARDUINO UNO
}

\author{
HERLAMBANG SYAH PRIO, ROBIN SEIADI, DWI PRIYOKUSUMO, \& MAULUDI \\ MANFALUTHY ${ }^{1)}$ \\ Program Studi Teknik Elektro, Sekolah Tinggi Teknologi Jakarta \\ Email:mauludi@sttj.ac.id ${ }^{1)}$
}

\begin{abstract}
There are many devices that can be used to communicate, where communication is information that can be conveyed in the form of data, news or messages in the form of symbols / signs, writing, pictures, or sounds. This study aims to create an alternative device by utilizing FM radio waves, the text sent by FM Transmitter will be received and processed into text and displayed on the LCD on the side of the receiver. As input is used Keyboard PS / 2, Arduino Uno with ATMega328P Chip IC to process data, FM Transmitter as a signal sender ,FM Receiver and $L C D$ to receive and display text. The results show that text can be sent and received well when in and outside the room. Outdoor text can be sent and received well within a distance of $\leq 35$ meters with room temperature of 27 degree Celcius, and in the room text can be sent and received well within a distance of $\leq 37$ meters with room temperature of 25 degree Celsius. Temperature can affect the quality of the signal sent and received by the FM radio, so that outside the text can be sent and received well within a distance of $\leq 26$ meters with 61 degree Celsius temperature.
\end{abstract}

Keywords: Telecommunication, Text, FM Radio Wave, Microcontroller.

\begin{abstract}
ABSTRAK
Banyak perangkat yang dapat digunakan untuk berkomunikasi, dimana komunikasi merupakan sebuah informasi yang dapat disampaikan berupa data, berita atau pesan dalam bentuk simbol/ tanda, tulisan, gambar, atau suara. Penelitian ini bertujuan untuk membuat alternatif alat telekomunikasi dengan memanfaatkan gelombang radio FM, text yang dikirimkan oleh FM Transmitter akan diterima dan diolah menjadi text dan ditampilkan pada LCD di sisi receiver. Sebagai input digunakan Keyboard PS/2, Arduino Uno dengan IC Chip ATMega328P untuk mengolah data, FM Transmitter sebagai pengirim sinyal dan FM Receiver serta LCD untuk menampilkan text. Hasil penelitian menunjukan bahwa text dapat dikirim dan diterima dengan baik saat berada di dalam dan diluar ruangan. Di luar ruangan text dapat dikirim dan diterima dengan baik dalam jarak $\leq 35$ meter dengan suhu ruang $27^{\circ} \mathrm{C}$, dan di dalam ruangan text dapat dikirim dan diterima dengan baik dalam jarak $\leq 37$ meter dengan suhu ruang $25^{\circ} \mathrm{C}$. Suhu dapat mempengaruhi kualitas sinyal yang dikirim dan diterima oleh radio FM, sehingga diluar ruangan text dapat dikirim dan diterima dengan baik hanya dalam jarak $\leq 26$ meter dengan suhu $61^{\circ} \mathrm{C}$.
\end{abstract}

Kata Kunci: Telekomunikasi, Text, Gelombang Radio FM, Mikrokontroler. 


\section{PENDAHULUAN}

Tidak terbantahkan bahwa Komunikasi merupakan hal yang sangat dibutuhkan dalam memperoleh informasi dan berita pada saat ini. Dengan berkomunikasi kita dapat bertukar informasi dalam bentuk teks/pesan, gambar atau data. Salah satu cara manusia untuk berkomunikasi yaitu berupa ungkapan yang di buat dengan teks/pesan dimana tulisan tersebut akan di sampaikan kepada orang lain. Kita sudah mengenal banyak sekali media komunikasi baik gelombang radio (Wifi dan selular) maupun kabel, namun pada saat tertentu di lokasi tertentu terkadang kita tidak mendapatkan gelombang wifi atau selular tertutama didaerah pinggiran kota besar, dimana jalan raya penghubung antar provinsi memerlukan sign board untuk pengguna jalan, Disamping itu biaya menggunakan wifi atau selular lebih mahal jika dibandingkan dengan gelombang radio FM. Karena itulah pada penelitian ini dibuat alat komunikasi untuk mengirim text melalui sinyal FM berbasis arduino uno. Kita bisa mengunakan alat ini untuk mengirim text diruang lingkup sekolah, perkantoran, ataupun untuk membuat sebuah billboard sejauh ruang lingkup transmisi sinyal FM yang dipancarkan.

\section{TINJAUAN PUSTAKA}

a. Modulasi Frekuensi (FM)

Modulasi frekuensi (FM) adalah metode untuk menyampaikan informasi melalui gelombang pembawa dengan memvariasikan frekuensi, hali ini berbeda dengan sistem Modulasi Amplitudo (AM) dimana sistem AM amplitudo dari gelombang pembawa yang bervariasi sedangkan frekuensi tetap konstan. Modulasi frekuensi didefinisikan sebagai deviasi frekuensi sesaat sinyal pembawa (dari frekuensi tak termodulasinya) sesuai dengan amplitudo sesaat sinyal pemodulasi. Di awal perkembangannya, radio broadcasting memakai sistem transmisi AM (Amplitudo Modulasi), tetapi karena sinyal transmisi AM mempunyai banyak kelemahan, antara lain mudah terganggu oleh sumber medan listrik-magnit luar seperti, dinamo, petir, lampu neon, dsb, maka tidak cocok untuk menyalurkan informasi Audio yang mempunyai kualitas $\mathrm{Hi}-\mathrm{Fi}$. Frekuensi yang dialokasikan untuk siaran FM berada di antara 88-108 MHz[1].
Frekuensi tersebut relatif lebih aman dari gangguan cuaca buruk sehingga dapat menghasilkan suara dengan kualitas yang lebih baik. Gelombang radio FM memiliki panjang gelombang yang lebih pendek dari pada gelombang AM sehingga gangguan yang diakibatkan oleh penurunan daya hampir tidak berpengaruh. Selain itu, sinyal yang dikirimkan melalui gelombang radio FM juga mampu menggabungkan sinyal suara untuk menghasilkan suara dengan kualitas stereo. Tak heran jika banyak statiun radio modern menggunakan pemancar radio FM agar dapat menyajikan acara-acara dengan suara yang lebih berkualitas kepada pendengarnya, khususnya acara musik di radio.

\section{b. Arduino Uno}

Arduino adalah pengendali mikro single-board yang bersifat open-source, diturunkan dari Wiring platform, dirancang untuk memudahkan penggunaan elektronik dalam berbagai bidang. Hardware-nya memiliki prosesor Atmel AVR dan softwarenya memiliki bahasa pemrograman sendiri[2].

Arduino juga merupakan platform hardware terbuka yang ditujukan kepada siapa saja yang ingin membuat purwarupa peralatan elektronik interaktif berdasarkan hardware dan software yang fleksibel dan mudah digunakan. Mikrokontroler diprogram menggunakan bahasa pemrograman arduino yang memiliki kemiripan syntax dengan bahasa pemrograman C. Karena sifatnya yang terbuka maka siapa saja dapat mengunduh skema hardware arduino dan membangunnya.

IDE merupakan kependekan dari Integrated Development Environment, atau merupakan lingkungan terintegrasi yang digunakan untuk melakukan pengembangan. Disebut sebagai lingkungan karena melalui software inilah Arduino dilakukan pemrograman untuk melakukan fungsi-fungsi yang dibenamkan melalui sintaks pemrograman. Arduino menggunakan bahasa pemrograman sendiri yang menyerupai bahasa C. Bahasa pemrograman Arduino (Sketch) sudah dilakukan perubahan untuk memudahkan pemula dalam melakukan pemrograman dari bahasa aslinya. Sebelum dijual ke pasaran, IC mikrokontroler Arduino telah ditanamkan suatu program bernama Bootlader yang ber- 
fungsi sebagai penengah antara compiler Arduino dengan mikrokontroler.
Skematik Rangkaian Arduino Uno dapat dilihat pada gambar 1 .

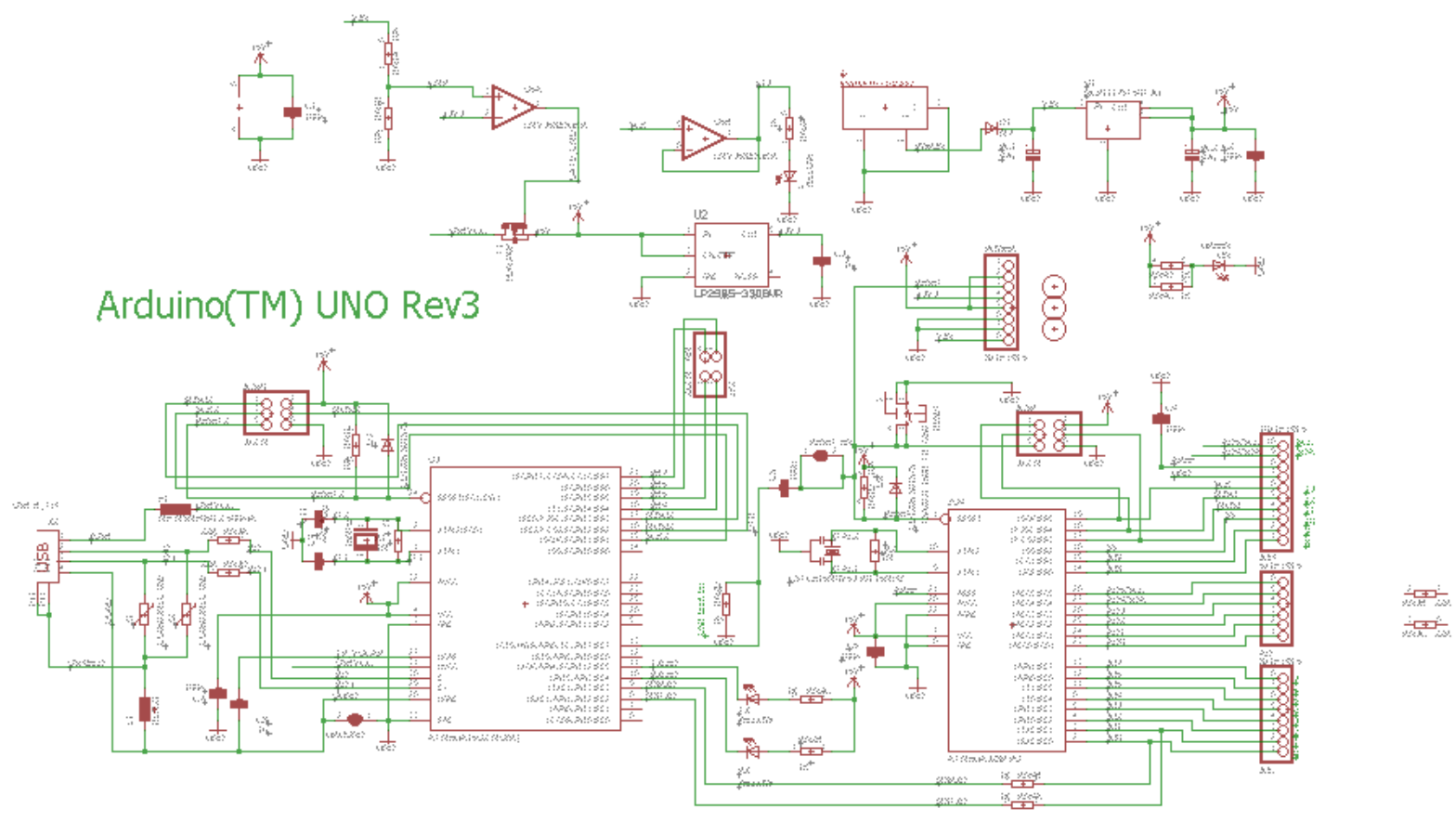

Gambar 1 Skematik Arduino Uno R3

\section{c. Liquid Crystal Display (LCD) 16X2}

LCD (Liquid Crystal Display) adalah suatu jenis media tampil yang menggunakan kristal cair sebagai penampil utama. LCD sudah digunakan diberbagai bidang misalnya alal-alat elektronik seperti televisi, kalkulator, atau pun layar komputer. Pada postingan aplikasi LCD yang digunakan ialah LCD dot matrik dengan jumlah karakter $2 \times 16$. LCD sangat berfungsi sebagai penampil yang nantinya akan digunakan untuk menampilkan status kerja alat[3].

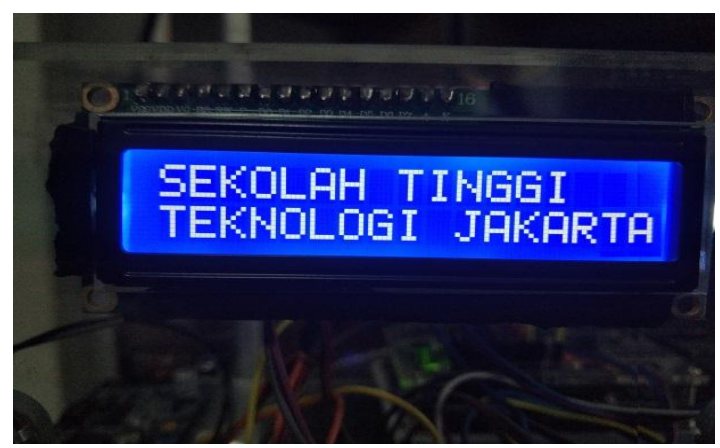

Gambar 2. LCD (Liquid Crystal Display).

\section{d. PS/2 Keyboard}

Keyboard adalah alat input dan merupakan salah satu perangkat keras kom-puter yang memiliki macam-macam tombol yang memiliki fungsi yang berbeda tergantung pada penekanannya yang dapat meng-hasilkan proses sesuai dengan kemauan kita. Dari fungsi di atas dapat diketahui juga bahwa fungsi dari sebuah keyboard adalah untuk memberikan perintah kepada komputer untuk melaksanakan pengolahan data meng-gunakan perangkat lunak. Keyboard, mempunyai fungsi utama sebagai alat ketik, sesuai dengan namanya yaitu papan ketik. Keyboard bertugas untuk menampilkan angka, huruf, dan simbol pada layar monitor komputer Anda yang kemudian dicetak menjadi dokumen atau memang sengaja dibuat sebagai data digital di komputer. Keyboard pada dasarnya tidak selalu mengeluarkan output berupa angka, huruf, dan simbol[4]. 


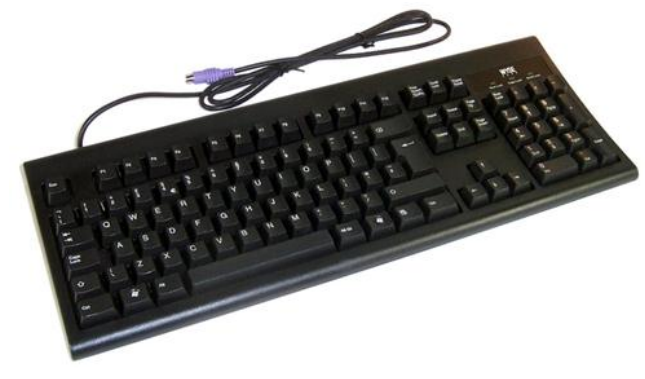

Gambar 3. Keyboard PS2

\section{e. Boudot Kode}

Boudot adalah pendahulu Alphabet Internasional Telegraph No 2 (ITA2), Kode ini dimasukkan pada keyboard yang memiliki hanya lima kunci jenis piano, dioperasikan dengan dua jari dari tangan kiri dan tiga jari tangan kanan. Setelah tombol telah ditekan mereka dikunci bawah sampai kontak mekanis dalam unit distributor melewati sektor yang terhubung ke keyboard tertentu, ketika keyboard tidak dikunci siap untuk karakter berikutnya yang akan dimasukkan, dengan klik terdengar (dikenal sebagai "irama sinyal") untuk memperingatkan operator. Operator harus mempertahankan ritme stabil, dan kecepatan biasa operasi adalah 30 kata per menit[5].

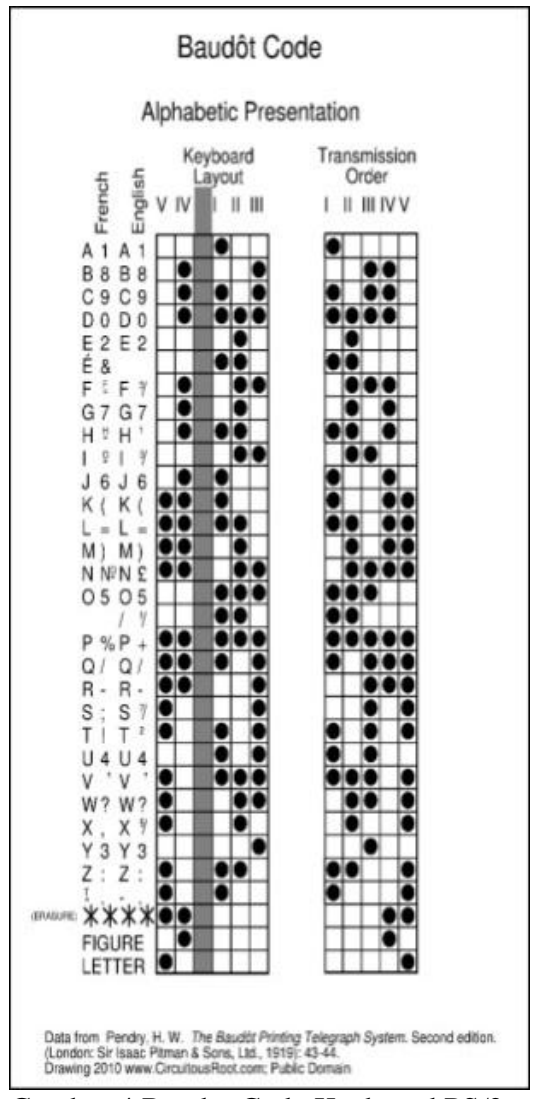

Gambar 4 Baudot Code Keyboard PS/2

\section{e. FM Transmitter}

FM Transmitter adalah sebuah devicel alat yang bisa berfungsi untuk memancarkan sinyal radio (FM) sehingga gelombang suara yang dipancarkan bisa diterima oleh FM Receiver (Radio ataupun Car Audio)[6].

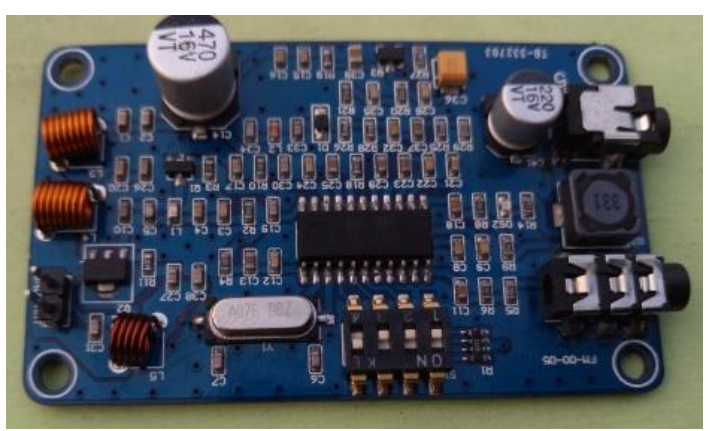

Gambar 5 Transmitter PLL BH1417

\section{f. Antena}

Antena adalah untuk mengubah sinyal listrik menjadi sinyal elektromagnetik, lalu meradiasikannya (Pelepasan energy elektromagnetik ke udara/ruang bebas). Dan sebaliknya, antena juga dapat berfungsi untuk menerima sinyal elektromagnetik (Penerima energy elektromagnetik dari ruang bebas ) dan mengubahnya menjadi sinyal listrik[7].

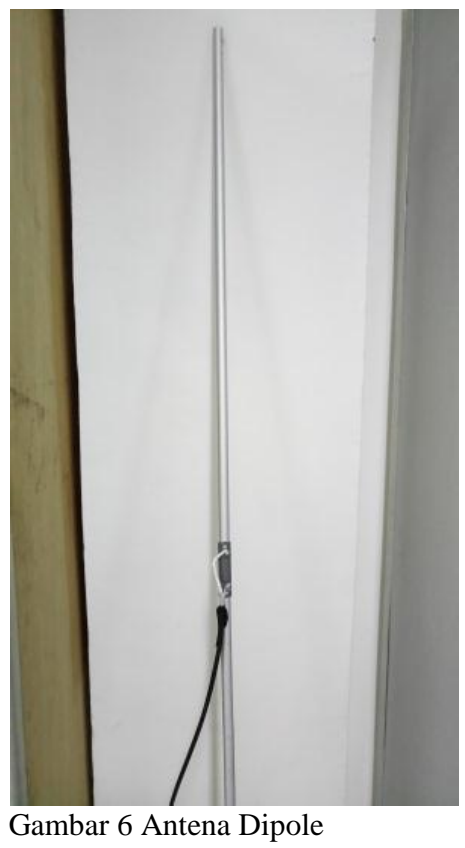

\section{g. Demodulator}

Demodulasi FM adalah proses sebaliknya dari modulasi FM, yaitu proses suatu sinyal modulasi yang dibentuk kembali seperti aslinya dari suatu gelombang pembawa (carrier wave) yang termodulasi oleh rangkaian. 
Proses terjadinya demodulasi terjadi pada alat untuk melakukan demodulasi yaitu demodulator atau detektor. Definisi demodulator sendiri adalah rangkaian yang penerima komunikasi (radio, televisi, dan radar) yang berfungsi memisahkan informasi asli dari gelombang campuran (yaitu gelombang isyarat pembawa yang termodulasi. Demodulator sering juga disebut dengan detector. Dalam system modulasi frekuensi (FM) diterapkan rangkaian demodulator yang disebut diskriminator. Sesudah isyarat informasi dipisahkan dari gelombang campuran, maka isyarat informasi itu dikuatkan dan ditampilkan sebagai bunyi atau tanda-tanda lain (misalnya bayangan seperti dalam televisi)

\section{METODE PENELITIAN}

Penelitian ini terdiri dari tiga tahap yaitu: 1. Perancangan 2. Pembuatan dan 3. Pengujian.

\section{a. Perancangan}

Output dari perancangan ini terdiri dari spesifikasi peralatan yang ingin dihasilkan berupa adalah alat untuk mengirim text melalui sinyal FM. Kita bisa mengunakan alat ini untuk mengirim text diruang lingkup sekolah, perkantoran, ataupun untuk mem-

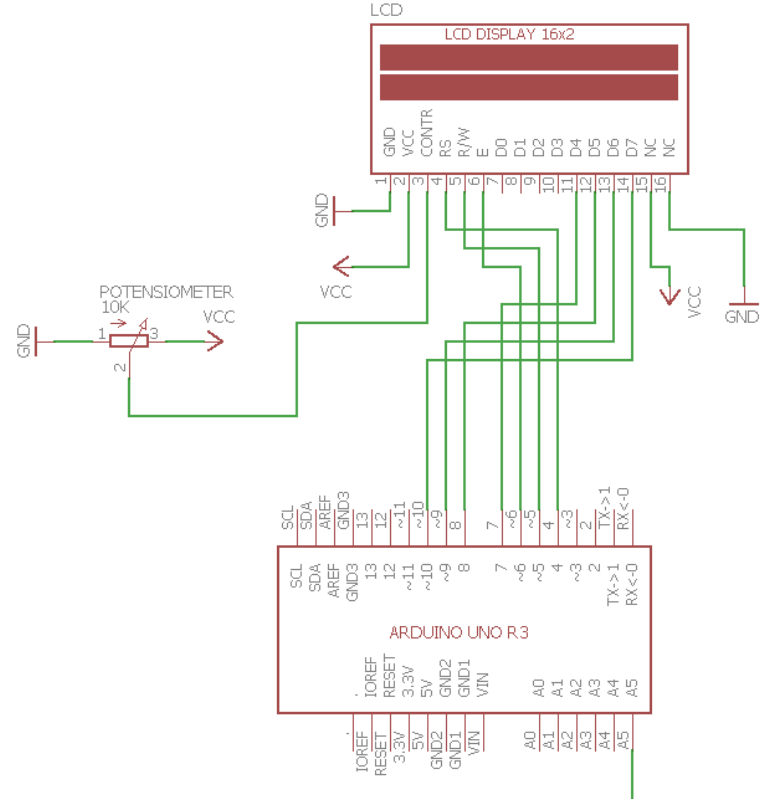

buat sebuah billboard sejauh ruang lingkup sinyal FM. Sinyal FM akan diterima oleh FM Receiver, dan di demodulasi untuk ditampilkan pada LCD 16X2 berupa text.

Gambar 7 menunjukan diagram block peracangan peralatan Pengirim Text dengan gelombang FM berbasis Arduino Uno.

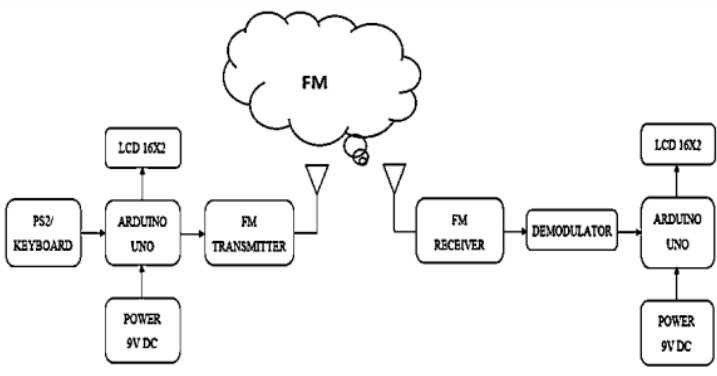

Gambar 7 Block Diagram Perancangan Pengiriman Text Berbasis Arduino Uno

\section{b. Gambar Rangkaian}

Setelah mempelajari beberapa literatur, penulis merancang suatu rangkaian yang akan digunakan untuk menerima text melalui sinyal FM berbasis arduino uno. Rangkaian keseluruhan dari alat ini dapat dilihat pada Gambar 8.

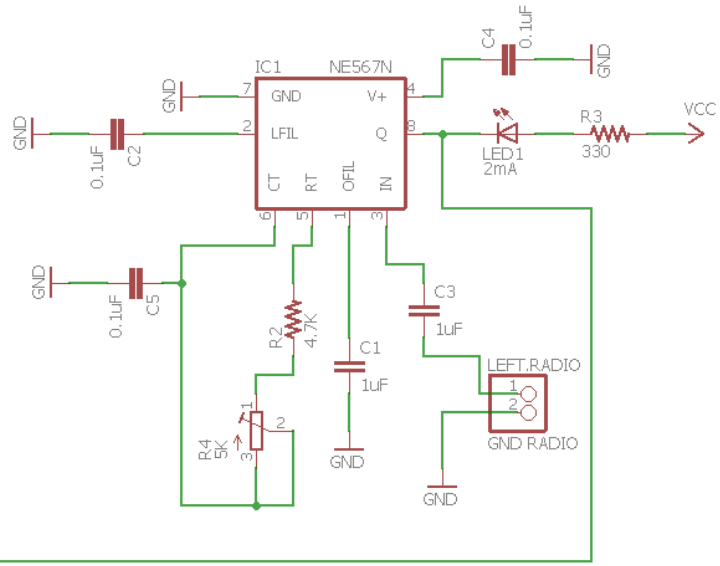

Gambar 8 Rangkaian Keseluruhan 


\section{c. Rangkaian Demodulator}

Rangkaian Demodulator ini menggunakan IC LM567CN, dimana pada IC LM567
$\mathrm{CN}$ ini memiliki 8 kaki [5]. Untuk rangkaian demodulator dapat dilihat pada Gambar 9.

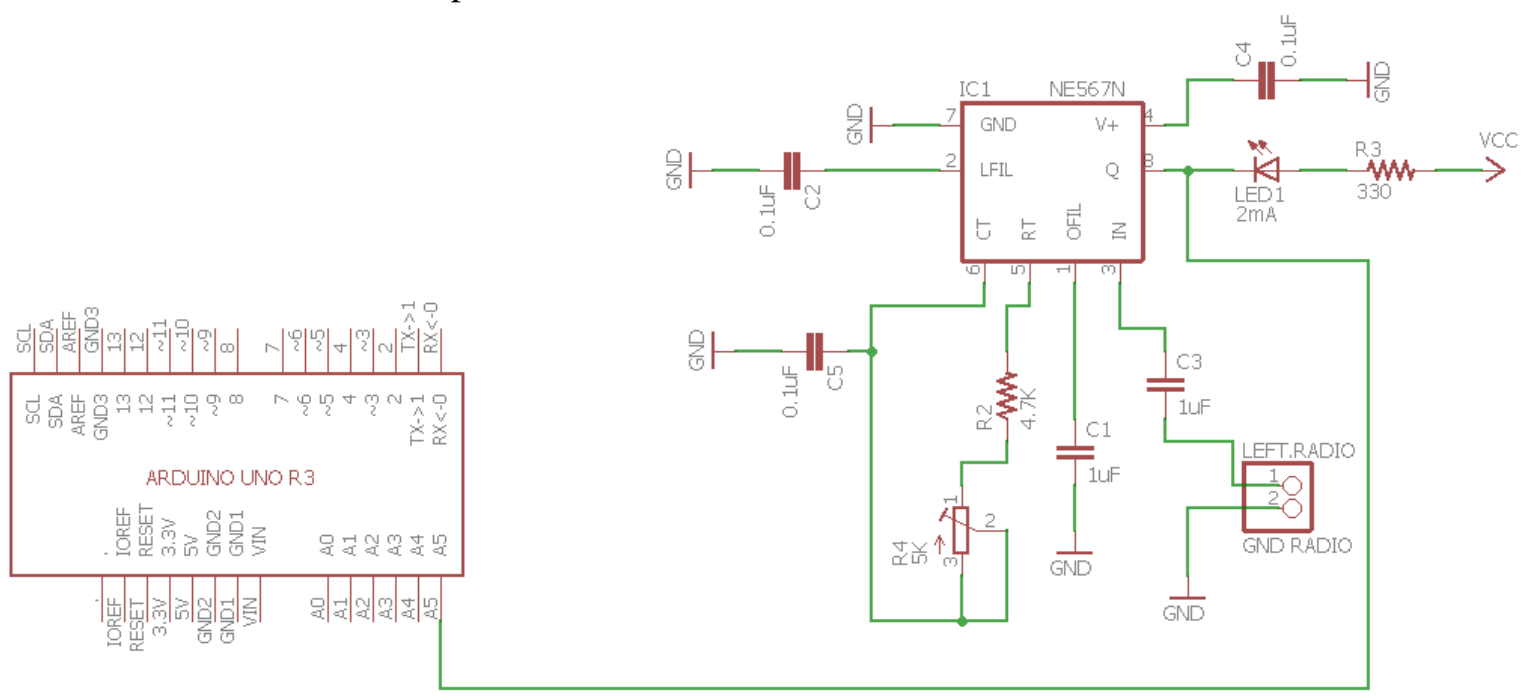

Gambar 9 Koneksi Demodulator ke Arduino

\section{d. Rangkaian LCD 16x2}

Penulis menggunakan rangkaian LCD $16 \times 2$ ini untuk menampilkan text yang telah diolah oleh arduino. Setelah arduino menerima data yang telah didemodulasi oleh demodulator, kemudian arduino mengolah data tersebut sesuai dengan sketch/pemrograman yang telah di upload. Arduino akan mengirimkan hasil pengolahan tersebut ke LCD 16x2. Untuk lebih jelasnya dapat dilihat pada Gambar 10.

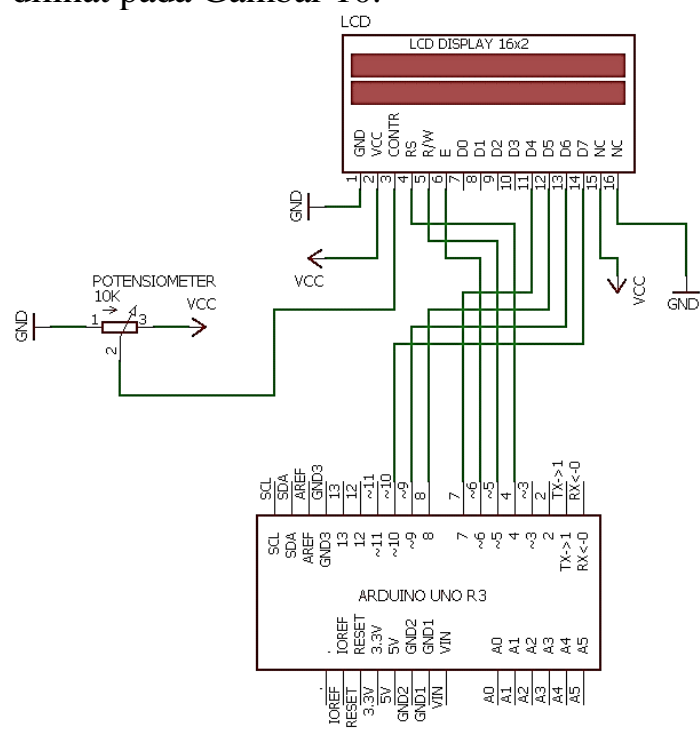

Gambar 10 Koneksi LCD ke Arduino Uno

\section{e. Pembuatan}

Pada tahap pembuatan ini yaitu merealisasikan rancangan yang telah dibuat sebelumnya sehingga menjadi sebuah peralatan FM Transmitter dan Receiver Sebagai Penerima Text Berbasis Arduino Uno. Hasil peralatan dapat dilihat pada gambar 11 dan gambar 12.

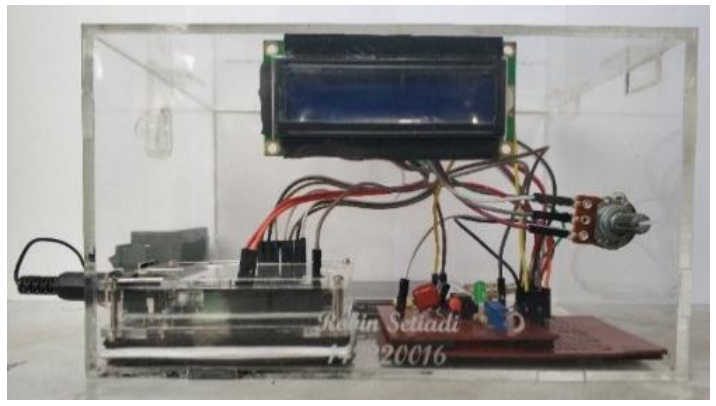

Gambar 11. Peralatan FM Receiver Sebagai Penerima Text Berbasis Arduino Uno.

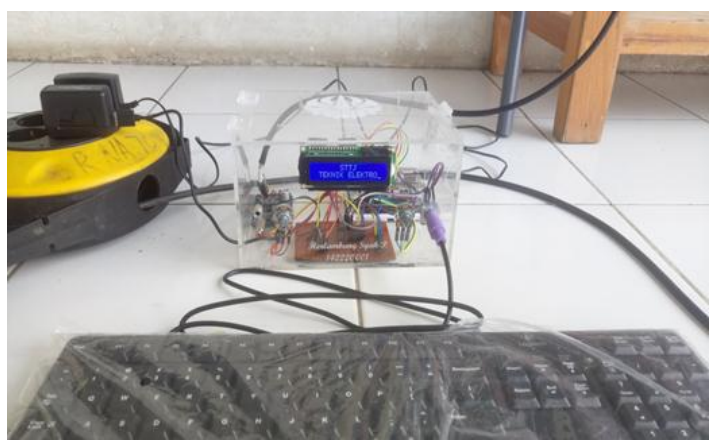

Gambar 12. Peralatan FM Transceiver Sebagai Pengirim Text Berbasis Arduino Uno. 


\section{f. Cara Kerja Alat}

Tekan saklar ON/OFF untuk menghidupkan alat, setelah alat hidup nyalakan FM Receiver (radio) dan pilih frekuensi yang sama dengan FM Transmitter. Kemudian atur/adjust demodulator dengan cara memutar Multi Rotation VR 5K $\Omega$ (Trim) hingga Light Emitting Diode (LED) berkedip secara konstan/teratur.

Sinyal FM yang diterima oleh antena akan masuk ke FM Receiver (radio), pada FM Receiver sinyal tersebut mengalami decode, demodulasi, dan penguatan. Setelah itu informasi tersebut akan masuk ke demodulator dan di demodulasi menjadi data yang dibutuhkan sebelum masuk ke board arduino. Pada arduino, data tersebut akan diolah sedemikian rupa sesuai dengan sketch/pemograman yang sebelumnya telah di upload pada board arduino. Hasil dari data yang telah diolah oleh arduino akan ditampilkannya pada layar Liquid Crystal Display (LCD) $16 \times 2$.

\section{g. Pengujian}

Pada tahap pengujian ini akan diuji seberapa jauh jarak maksimal $F M$ receiver dapat menerima text yang dikirimkan oleh FM Transmitter, baik didalam ruangan maupun diluar ruangan. Pengujian dilakukan dengan cara FM Transmitter mengirimkan text secara konstan/stabil dan terus-menerus, kemudian FM Receiver dijauhkan sedikit demi sedikit dan berhenti ketika text sudah tidak diterima atau tidak sesuai dengan yang dikirim oleh FM Transmitter.

\section{HASIL PENGUKURAN DAN ANALI-} SA

\section{a. Hasil Pengukuran}

1. Pengukuran Di Dalam Ruangan

Tabel 1 Hasil Pengukuran Dalam Ruangan

\begin{tabular}{|c|c|c|c|}
\hline \multicolumn{4}{|c|}{ Dalam Ruangan } \\
\hline Frekuensi & Waktu & Suhu & Jarak \\
\hline \multirow{4}{*}{$107.9 \mathrm{MHZ}$} & 07.00 & $26^{\circ} \mathrm{C}$ & $35 \mathrm{~m}$ \\
\cline { 2 - 4 } & 13.00 & $28^{\circ} \mathrm{C}$ & $33 \mathrm{~m}$ \\
\cline { 2 - 4 } & 16.00 & $27^{\circ} \mathrm{C}$ & $34 \mathrm{~m}$ \\
\cline { 2 - 4 } & 20.00 & $25^{\circ} \mathrm{C}$ & $37 \mathrm{~m}$ \\
\hline
\end{tabular}

2. Pengukuran Di Luar Ruangan

Tabel 2. Hasil Pengukuran Luar Ruangan.

\begin{tabular}{|c|c|c|c|}
\hline \multicolumn{4}{|c|}{ Luar Ruangan } \\
\hline Frekuensi & Waktu & Suhu & Jarak \\
\hline \multirow{4}{*}{$107.9 \mathrm{MHZ}$} & 07.00 & $30^{\circ} \mathrm{C}$ & $33 \mathrm{~m}$ \\
\cline { 2 - 4 } & 13.00 & $61^{\circ} \mathrm{C}$ & $32 \mathrm{~m}$ \\
\cline { 2 - 4 } & 16.00 & $45^{\circ} \mathrm{C}$ & $34 \mathrm{~m}$ \\
\cline { 2 - 4 } & 20.00 & $27^{\circ} \mathrm{C}$ & $35 \mathrm{~m}$ \\
\hline
\end{tabular}

3. Grafik Jarak Transmisi

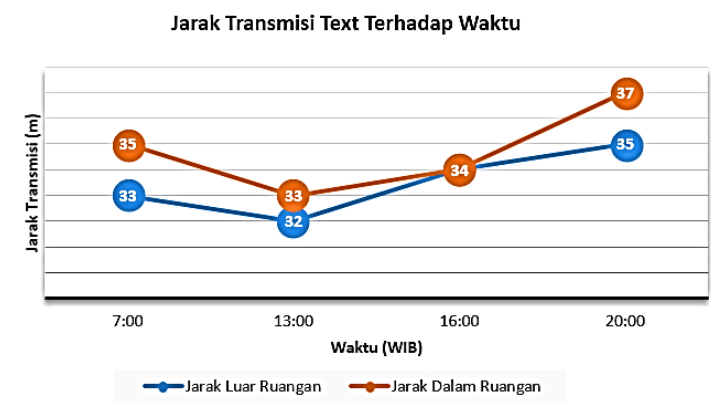

Gambar 13 Grafik Jarak Transmisi Terhadap Waktu

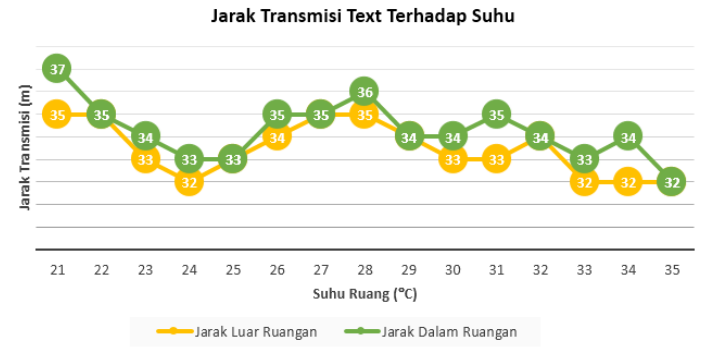

Gambar 14 Grafik Jarak Transmisi Terhadap Suhu

\section{b. Analisa}

Berdasarkan data pengukuran diatas didapatkan beberapa hasil analisa yaitu:

1. Sinyal yang digunakan oleh penulis adalah 107.9 MHZ.

2. Suhu tidak mempengaruhi kualitas sinyal FM yang ditransmisikan oleh FM Transmitter

3. Di dalam dan diluar ruangan kualitas trasnmisi sinyal FM dapat diterima dengan baik.

4. Jarak maksimal text yang dapat di kirim dan diterima adalah 35-37 meter.

\section{KESIMPULAN}

Setelah dilakukan pengujian hasil perancangan alat "FM Receiver Sebagai Penerima Text Berbasis Arduino Uno", dapat diambil beberapa kesimpulan: 
1. Data text dapat diterima dengan baik, selama dalam jarak transmisi $F M$ Transmitter.

2. Suhu tidak mempengaruhi kualitas sinyal FM dan jarak yang diterima.

3. Alat ini dapat bekerja dengan baik di dalam dan diluar ruangan.

\section{Saran}

Berdasarkan kesimpulan diatas, maka penulis mencoba memberikan saran untuk peningkatan fungsi dan sistem FM Receiver Sebagai Penerima Text Berbasis Arduino Uno, sebagai berikut:

1. Untuk meningkatkan efisiensi alat ini, penulis merekomendasikan untuk menggunakan rangkaian demodulator yang lebih baik.

2. Untuk mengurangi noise yang diterima, direkomendasikan untuk menggunakan FM Receiver (radio) yang memiliki noise yang kecil.

3. Penulis merekomendasikan untuk menggunakan frekuensi yang tidak terdapat siaran radio lain.

\section{DAFTAR PUSTAKA}

[1] Arduino Uno, diakses 08 April 2018, https://id.wikipedia.org/wiki/Arduino

[2] Arduino Uno, diakses 08 April 2018, https://www.arduino.cc/

[3] Radio FM, diakses 12 April 2018, https://id.wikipedia.org/wiki/Radio_f m\#cite_note-1

[4] Radio FM, diakses 12 April 2018, https://id.wikipedia.org/wiki/Radio

[5] IC LM567CN, diakses 12 April 2018, web.mit.edu/course/6/6.115/www/doc ument/lm567.pdf

[6] LCD 16x2, diakses 14 April 2018, https://www.sparkfun.com/datasheets/ LCD/ADM1602K-NSW-FBS3.3v.pdf

[7] Timer Library, FlexiTimer2 Library, PS2Keyboard Library, diakses 05 April 2018, http://playground.arduino.cc 